\title{
Partial replacement of soybean meal with pumpkin seed cake in lamb diets: Effects on carcass traits, haemato-chemical parameters and fatty acids in meat
}

\author{
Z. Antunović ${ }^{1}$, Ž. Klir ${ }^{1 \#}$, M. Šperanda ${ }^{1}$, V. Sičaja ${ }^{1}$, D. Čolović ${ }^{2}$, B. Mioč ${ }^{3}$ \& J. Novoselec ${ }^{1}$ \\ ${ }^{1}$ Department for Animal Husbandry, Faculty of Agriculture in Osijek, Josip Juraj Strossmayer University of Osijek, V. \\ Preloga 1, Osijek, 31000, Croatia \\ ${ }^{2}$ Institute of Food Technology in Novi Sad, Bulevar cara Lazara 1, 21000 Novi Sad, Serbia \\ ${ }^{3}$ Department of Animal Science and Technology, Faculty of Agriculture, University of Zagreb, Svetošimunska cesta 25, \\ Zagreb, Croatia
}

(Received 6 December 2017; Accepted 5 June 2018; First published online 22 August 2018)

Copyright resides with the authors in terms of the Creative Commons Attribution 4.0 South African Licence. See: http://creativecommons.org/licenses/by/4.0/za

Condition of use: The user may copy, distribute, transmit and adapt the work, but must recognise the authors and the South African Journal of Animal Science.

\begin{abstract}
The composition of lamb diets has an effect on production traits and meat quality, especially fatty acid proportions. Recently, in organic farming, soybean meal has frequently been replaced with feedstuffs that are rich in protein. The aim of the present study was to determine the effects of partial replacement of soybean meal with pumpkin seed cake on carcass traits, biochemical parameters and fatty acids of lamb meat produced in organic farming. The research was carried out on 70-day-old lambs of the Merinolandschaf breed. Thirty-six lambs were grouped by gender, and allotted to three treatment groups, which were given one of the three diets: control diet with no pumpkin seed cake; a diet in which $10 \%$ of soybean meal was replaced with $10 \%$ pumpkin seed cake; and a diet in which $15 \%$ of soybean meal was replaced with $15 \%$ pumpkin seed cake. The experimental feeding period was 30 days. Hay and water were provided ad libitum. Differential blood tests and haematological parameters were determined, and the concentrations of minerals and biochemical parameters, and enzyme activity were ascertained in blood serum. Carcass traits and lamb meat colour did not differ among dietary treatments. Significant differences were observed in the concentrations of some biochemical parameters, which indicated good energy and protein balance, and changes in fat metabolism that did not impair antioxidant status. Compared with the control, the concentration of linoleic acid (C18:2 n-6) was higher in diets containing $10 \%$ and $15 \%$ of pumpkin seed cake replacements. The results indicated that partial replacement of soybean meal with $10 \%$ or $15 \%$ of pumpkin seed cake could be implemented in lamb feeding in organic farming without major changes in carcass traits, haemato-chemical parameters and the fatty acid profile in meat.
\end{abstract}

Keywords: Blood parameters, meat quality, Merinolandschaf lambs, organic farming

${ }^{\#}$ Corresponding author: zklir@pfos.hr

\section{Introduction}

Organic livestock farming should comply with high animal welfare standards and meet animal behavioural needs. Animal health management should be based on disease prevention. Feedstuffs for livestock should be organically produced, preferably on the holding itself or on neighbouring organic farms (Official Journal of the European Union (OJ), 2007).

The success of organic sheep farming depends exclusively on the quality of feedstuffs used, which influences the production and quality of products produced (Rahmann, 2009). Well-balanced diets with added protein sources organically produced, improve the production and health of sheep (Sarhan, 2011). Along with monitoring the production process, it is necessary to supervise the haemato-chemical parameters of animals in organic production systems (Antunović et al., 2017a). In organic farming, as many organic feedstuffs as possible should be produced locally. Since the use of genetically modified material is prohibited, soybean and its by-products, usually a major source of protein in animal diets, have been prohibited in animal diets in organic farming systems because of their doubtful quality and origin (Hewlett \& 
Azeez, 2008). Therefore, as alternatives to soybean products, other organically produced feedstuffs and byproducts that are rich in protein have to be used in animal diets (Alves et al., 2016, Antunović et al., 2017b). Enishi et al. (2004) reported that pumpkin is a valuable feedstuff for ruminants because of its high content of total digestible nutrients, digestible energy and metabolizable energy. Pumpkin seed is also an excellent source of protein, minerals, vitamins and unsaturated fatty acids (Juranovic et al., 2003; Siegmund \& Murkovic, 2004; Glew et al., 2006). Zdunczyk et al. (1999) pointed out that pumpkin seed cake contains more crude protein than soybean meal $(598 \mathrm{~g} / \mathrm{kg}$ versus $474.2 \mathrm{~g} / \mathrm{kg}$, respectively). According to Murković et al. (1996), the lipids in pumpkin seed contains 35.6-60.8\% linoleic acid (LA) (C18:2 n-6), 21.0-46.9\% oleic acid (OA) (C18:1 n-9), 9.5-14.59\% palmitic acid (C16:0) and 3.1-7.4\% stearic acid (C18:0) with a favourable ratio of polyunsaturated (PUFA) to saturated fatty acids (SFA). Pumpkin seed cake also improves the palatability of concentrates for ruminants.

Ruminant meat has long been a sought-after source of nutrients as an integral part of healthy and balanced human diets (Adeyemi et al., 2016). Numerous research have established the influence of feeding on the fatty acid profile in lamb's meat when feeding lambs with diets rich in PUFA (Demirel et al., 2006; Elmore et al., 2005; Ponnampalam et al., 2001). Pumpkin seed cake is a rich source of protein and fat, but there is apparently no research on the inclusion of pumpkin seed cake in sheep and lamb diets in organic farming systems. In dairy goat diets, a complete replacement of soybean meal with pumpkin seed cake showed no adverse effects on milk production or on the milk fatty acid profile (Klir et al., 2017). Therefore, the objective of the present study was to determine whether soybean meal could be replaced with pumpkin seed cake in slaughter lamb production, and to assess the effects of this replacement on carcass traits, haemato-chemical parameters and the fatty acid profile of lamb's meat produced under organic farming conditions.

\section{Material and Methods}

The research was carried out on a certified organic family farm in Osijek-Baranya County (Croatia), which has reared sheep organically for 10 years. The research involved 36 weaned Merinolandschaf lambs, 12 animals in three treatment groups, with an average bodyweight of $25.9 \pm 1.27 \mathrm{~kg}$. The lambs were 70 days old, with an equal sex ratio in each group (50\%: $\left.50 \%{ }^{\lambda}\right)$ and were healthy and in adequate condition. The lambs were fed a mixture of organic feedstuffs. A mineral premix (Panto Mineral L84) approved for use in organic farming of sheep and lambs was used. Lambs were offered hay and water ad libitum. Table 1 presents the ingredients of the isonitrogenous and isoenergetic feed mixtures and the clover-grass hay which contained cocksfoot (Dactylis glomerata L.), timothy grass (Phleum pratense L.), meadow fescue (Festuca pratensis Huds.), white clover (Trifolium repens L.) and Italian ryegrass (Lolium multiflorum L.). Soybean meal, which is rich in protein, was used in the diet for the control group. In the first experimental group pumpkin seed cake partially replaced $10 \%$ of the soybean meal. In the second experimental group pumpkin seed cake replaced $15 \%$ of the soybean meal. All feed mixtures were formulated to obtain similar energy and protein contents of the diets among groups (Table 1). The experiment lasted 30 days and was conducted during the winter season. Rearing and feeding of the lambs was conducted according to the Council Regulation (EC) No. 834/2007 on Organic Production and Labelling of Organic Products with Regard to Organic Production, Labelling and Control (Official Journal of the European Union (OJ), 2007). The Committee for Animal Welfare of the Faculty of Agriculture in Osijek approved that the research was carried out according to the legal provisions of the Animal Protection Act 2017 (Official Gazette No. 133, 2006; No. 37, 2013; No. 125, 2013).

The lambs were weighed at the beginning and end of the investigation. Feed was offered at the same time each day. Feed refusals were recorded to calculate voluntary feed intake, which was measured in the control and in the two experimental groups to be $0.898,0.819$ and $0.835 \mathrm{~kg}$ of feed mixture, respectively, and weight gains were $0.224,0.282$, and $0.227 \mathrm{~kg}$, respectively.

The chemical composition of the feed mixtures and hay is presented in Table 1. Crude protein content of feed samples was determined with the Kjeldahl method (Pearson, 1976), while ether extract content was established according to method described in Onwuka (2005). Crude fibre content was carried out by the Weende method (Offor et al., 2014) and neutral detergent fibre (NDF), as described by Foss (2001).

Five lambs $(3 \hat{0}: 2$ ) $)$ per group were selected to be similar in live bodyweight (Table 2). Samples of the meat (musculus semimembranosus) and carcass parameters were taken immediately after slaughtering and exsanguination on the farm. The $m$. semimembranosus from the hind leg and part of subcutaneous adipose tissue were removed. Meat samples were frozen at $-80{ }^{\circ} \mathrm{C}$. The skin was removed and the abdominal organs (rumen, stomach, spleen, intestine, and liver) and the thoracic cavity content (trachea with lungs and heart) were removed. Internal organs, skin, lower parts of the legs and carcass were weighed. On the Croatian market, lamb is usually sold as whole carcass with head and kidneys, and therefore these parts were not separated from the carcass or weighed separately. After that, a standard measure of lamb carcass 
development (linear measure) was determined, namely carcass length (os pubis-atlas and os pubis-first rib), the length of the hind legs (tuber calcanei-tuberculum ossis Ischia) and the circumference of the leg (at the widest point). The carcass colour was determined in the $m$. semimembranosus 45 minutes after slaughtering. Values of colour was measured according to the CIE $L^{*} a^{*} b^{*}$ system (CIE, 1976) with a Minolta chroma meter CR-410 (Minolta Camera Co., Ltd., Japan). Triplicate readings were made for each sample and average values were recorded.

Table 1 Ingredients and chemical composition of the concentrate mixtures and the hay for the lambs

\begin{tabular}{|c|c|c|c|c|}
\hline \multirow{2}{*}{ Component } & \multicolumn{3}{|c|}{ Group } & \multirow{2}{*}{$\begin{array}{c}\text { Clover-grass } \\
\text { hay }\end{array}$} \\
\hline & T0 & T10 & T15 & \\
\hline \multicolumn{5}{|l|}{ Ingredient composition (\%) } \\
\hline Corn & 30.80 & 12.00 & 1.65 & \\
\hline Oat & 8.40 & 10.20 & 8.40 & \\
\hline Barley & 18.00 & 27.00 & 33.00 & \\
\hline Triticale & 19.80 & 28.90 & 35.45 & \\
\hline Soybean meal & 20.00 & 8.90 & 3.50 & \\
\hline Pumpkin seed cake & 0.00 & 10.00 & 15.00 & \\
\hline Mineral premix ${ }^{*}$ & 3.00 & 3.00 & 3.00 & \\
\hline \multicolumn{5}{|c|}{ Chemical composition (g/kg) } \\
\hline Dry matter & 877.50 & 884.70 & 891.50 & 890.60 \\
\hline Crude protein & 172.10 & 177.70 & 179.00 & 149.70 \\
\hline Ether extract & 18.80 & 31.70 & 43.30 & 13.30 \\
\hline Crude fibre & 38.60 & 41.40 & 38.80 & 259.00 \\
\hline Ash & 67.20 & 61.10 & 66.50 & 86.40 \\
\hline NDF & 98.60 & 157.00 & 145.80 & 510.80 \\
\hline NET & 581.30 & 572.80 & 563.50 & 382.70 \\
\hline \multicolumn{5}{|l|}{ Fatty acids (g/100 g) } \\
\hline C14:0 & 0.15 & 0.19 & 0.24 & 0.37 \\
\hline $\mathrm{C} 16: 0$ & 16.74 & 16.81 & 16.26 & 26.52 \\
\hline C16:1 & 0.24 & 0.28 & 0.26 & 1.67 \\
\hline C18:0 & 2.99 & 4.09 & 5.16 & 0.52 \\
\hline C18:1 & 24.94 & 29.64 & 32.42 & 4.57 \\
\hline C18:2 n6 (LA) & 50.58 & 45.87 & 43.41 & 17.90 \\
\hline C18:3 n3 (ALA) & 3.46 & 2.28 & 1.60 & 25.55 \\
\hline C20:0 & 0.44 & 0.35 & 0.38 & 21.98 \\
\hline C20:1 n9 & 0.46 & 0.51 & 0.25 & 0.91 \\
\hline SFA & 20.32 & 21.44 & 22.04 & 49.39 \\
\hline PUFA & 54.04 & 48.15 & 45.01 & 43.45 \\
\hline
\end{tabular}

T0: control, T10: 10\% replacement of soybean meal with pumpkin seed cake, T15: 15\% replacement of soybean meal with pumpkin seed cake, NDF: neutral detergent fibre; NET: net energy; LA: linoleic acid; ALA: alpha-linolenic acid; SFA (saturated fatty acids): C10:0, C12:0, C13:0, C14:0, C16:0, C18:0, C20:0, C21:0, C23:0, C24:0

PUFA (polyunsaturated fatty acids): C18:2 c9 t11, C18:2, C18:3, C20:2, C20:3, C20:4, C22:2, C20:5, C22:6

*Mineral premix: 18\% Ca, 5\% P, 9,5\% Na, 2,00\% Mg, 400.000 IU vitamin A, 40.000 IU vitamin D, 500 mg vitamin E, 4.000 mg Zn, 2.000 mg Mn, 60 mg I, 10 mg Co, 50 mg Se

The fat phase for fatty acid (FA) analysis was extracted from the $m$. semimembranosus samples using the Folch method as recommended for isolation of total lipids, especially from animal tissues (Folch et al., 1957). Fatty acid methyl esters were prepared from the extracted lipids by the transmethylation method, 
which uses $14 \%$ wt. boron trifluoride/methanol solution (Čolović et al., 2012). Samples were analysed with a gas chromatographer (GC; Agilent 7890A system Agilent Technologies, CA, USA) with a flame ionization detector (GC-FID), and auto-injection module for liquid, equipped with a fused silica capillary column (Supelco SP-2560 capillary GC column $100 \mathrm{~m} \times 0.25 \mathrm{~mm}, \mathrm{~d} 0.20 \mu \mathrm{m}$ ). Helium was used as a carrier gas (purity $99.9997 \mathrm{vol} \%$, flow rate $1.5 \mathrm{~mL} / \mathrm{min}$, and pressure $1.092 \mathrm{bar}$ ). A total of $1 \mu \mathrm{L}$ of sample was injected in split regime with a ratio of $30: 1$. The regimen was: Initial temperature $140{ }^{\circ} \mathrm{C}$, hold time 5 min, heating rate $3{ }^{\circ} \mathrm{C} / \mathrm{min}$, final temperature $240{ }^{\circ} \mathrm{C}$, and final temperature hold time $10 \mathrm{~min}$. Nitrogen was used as a makeup gas. The FA peaks were identified by comparing retention times with those of standards from Supelco 37 component FA methyl ester mix and with data from the internal data library, based on previous experiments and FA methyl ester determination on gas chromatography-mass spectrometry (GC-MS). The results were expressed as a mass of individual FAs or FA group $(\mathrm{g})$ in $100 \mathrm{~g}$ of total FAs or as relative mass contents from two replicates.

Blood was collected from the jugular vein $(10 \mathrm{~mL})$ in sterile vacuum tubes (Venoject ${ }^{\circledR}$, Sterile Terumo, Leuven, Belgium) in the morning at the end of the study (30th day) from all experimental animals. After that, serum was separated by centrifugation (10 $\mathrm{min})$ at 3000 revolutions/min and placed in the Olympus AU640 analyser. In blood serum, the concentrations of minerals (calcium, phosphorus-inorganic and iron) were determined, and those of biochemical parameters: urea, glucose, total proteins, albumin, cholesterol, highdensity lipoprotein (HDL), low-density lipoprotein ( $\mathrm{LDL})$, triglyceride, $\beta$-hydroxybutyrate $(\mathrm{BHB})$ and nonesterified fatty acids (NEFA), and the activity of alanine aminotransferase (ALT, EC 2.6.1.2) and aspartate aminotransferase (AST. EC 2.6.1.1) enzymes were measured using Olympus System reagents (OSR) (Olympus Diagnostic $\mathrm{GmbH}$, Lismeehan, Ireland). Globulin content was calculated as the difference between total protein and albumin. Haematological parameters: number of leukocytes (WBC), erythrocytes (RBC) and thrombocyte (PLT), and the contents of haemoglobin, haematocrit, mean corpuscular volume (MCV), average haemoglobin content in erythrocytes $(\mathrm{MCH})$ and mean haemoglobin concentration in erythrocytes $(\mathrm{MCHC})$ in whole blood of sheep were determined on an automatic three differential haematology analyser (Sysmex PocH-100lv, Sysmex Europe GmbH, Hamburg, Germany). A differential blood test was carried out with a microscope using the prepared blood smears coloured according to Pappenheim staining. The activity of glutathione peroxidase (GPx, EC 1.11.1.9) in the serum was determined using a Ransel ${ }^{\circledR}$ kit (Randox, UK) on an automatic Olympus AU 400 (Olympus, Japan) analyser on a wavelength of $240 \mathrm{~nm}$. The principle of the reaction is based on the oxidation of glutathione with cumene hydroperoxide, with a catalytic activity of GPx. The resulting oxidized form of glutathione was immediately converted to a reduced form with the presence of glutathione reductase and nicotinamide adenine dinucleotide phosphate (NADPH) as an oxygen acceptor. Thereby, NADPH, on receiving oxygen, turned to the oxidized form NADP. The activity of total superoxide dismutase (SOD, EC 1.15.1.1) in serum was determined with a Ransod $₫$ kit (Randox, UK) on an automatic analyser (Olympus AU 400, Olympus, Japan) at a wavelength of $510 \mathrm{~nm}$. The method is based on the generation of superoxide radicals from xanthine by xanthine oxidase, which react with 2-(4-iodophenyl)3-(4nitrofenil) 5-phenyltetrazole chloride to form formazan red coloration.

The normality of the data was checked with the Shapiro-Wilk test. Parametric distributed data (haemato-chemical parameters) were presented as mean and standard deviation, and analysed with the ANOVA procedure, using feeding treatment as a fixed effect. Mean values were compared with the Tukey test and the differences between the groups were declared significant at $P<0.05$. Non-parametric data (carcass traits, colour, and FAs of meat) were presented as median, minimal and maximal values. These data were analysed with the Kruskal-Wallis $\mathrm{H}$ test. When $P<0.05$, the result was considered statistically significant. All data were analysed with statistical software SAS 9.4 ${ }^{\circledR}$ (SAS Institute Inc., 2002-2012).

\section{Results}

Replacing soybean meal with $10 \%$ or $15 \%$ of pumpkin seed cake did not influence $(P>0.05)$ the carcass traits of the lambs. Colour parameters of $m$. semimembranosus did not differ between groups (Table 2). Table 3 indicates no differences $(P>0.05)$ in haematological parameters of lambs in T10 and T15.

Changes in concentrations of NEFA, BHB, glucose, cholesterol, urea and albumin in serum were recorded $(P<0.05)$ by analysing the biochemical parameters (Table 4). Compared with the control group, serum of T15 had a lower concentration of cholesterol. Higher $(P<0.05)$ glucose and albumin, and lower $(P<0.05)$ NEFA and BHB concentrations were measured in the serum of lambs fed T10 and T15 compared with the control group. The activity of GPx did not differ $(P>0.05)$ among groups, while the activity of SOD was higher $(P$ $<0.05$ ) in groups fed $15 \%$ pumpkin seed cake than in the other groups. 
Table 2 Median (min-max) values of lambs' carcass traits and colour parameters of musculus semimembranosus

\begin{tabular}{|c|c|c|c|c|c|c|}
\hline \multirow{2}{*}{ Parameter } & \multicolumn{3}{|c|}{ Group } & \multirow{2}{*}{ SE } & \multicolumn{2}{|c|}{$P$-value } \\
\hline & TO & T10 & T15 & & T0/T10 & T0/T15 \\
\hline \multicolumn{7}{|l|}{ Carcass traits } \\
\hline Slaughter weight (kg) & $32.00(30.50-32.50)$ & $32.00(30.00-34.50)$ & $31.00(30.00-37.50)$ & 0.51 & 0.596 & 0.338 \\
\hline Carcass length $1(\mathrm{~cm})$ & $80.00(76.00-84.00)$ & $83.00(78.00-86.00)$ & $82.00(80.00-92.00)$ & 1.00 & 0.292 & 0.209 \\
\hline Carcass length $2(\mathrm{~cm})$ & $69.00(63.00-73.00)$ & $71.00(66.00-73.00)$ & $67.00(66.00-70.00$ & 0.85 & 0.340 & 0.833 \\
\hline Hind leg circumference $(\mathrm{cm})$ & $37.00(36.00-39.00$ & $36.50(36.00-39.00)$ & $37.00(35.00-39.00)$ & 0.34 & 0.830 & 0.916 \\
\hline Hind leg length (cm) & $33.00(30.00-36.00)$ & $35.00(34.00-37.00)$ & $34.00(33.00-37.00)$ & 0.49 & 0.073 & 0.167 \\
\hline Hot carcass weight (kg) & $16.50(16.00-17.00)$ & $16.00(15.50-17.00)$ & $16.00(16.00-20.00)$ & 0.28 & 0.381 & 0.910 \\
\hline Dressing (\%) & $52.31(50.77-53.13)$ & $50.00(48.44-53.33)$ & $53.33(51.61-54.84)$ & 0.47 & 0.116 & 0.056 \\
\hline Organs weight* $(\mathrm{kg})$ & $1.55(1.49-1.70)$ & $1.58(1.52-1.70)$ & $1.60(1.51-1.70)$ & 0.02 & 0.750 & 0.667 \\
\hline Forestomach and intestines $(\mathrm{kg})$ & $8.10(7.50-9.50)$ & $8.10(7.90-8.40)$ & $8.00(7.50-9.80)$ & 0.16 & 0.916 & 0.916 \\
\hline Skin and lower legs (kg) & $3.93(3.70-5.10)$ & $4.20(4.00-4.92)$ & $4.30(4.00-4.90)$ & 0.11 & 0.465 & 0.465 \\
\hline \multicolumn{7}{|c|}{ Colour parameters of $\mathbf{m}$. semimembranosus } \\
\hline Lightness $\left(L^{*}\right)$ & $41.50(40.06-47.90)$ & $41.43(39.97-47.96)$ & $42.97(35.48-44.23)$ & 0.90 & 0.807 & 0.807 \\
\hline Redness $\left(a^{\star}\right)$ & $20.44(19.64-21.18)$ & $20.74(20.19-21.21)$ & $20.47(18.33-22.08)$ & 0.23 & 0.462 & 0.807 \\
\hline Yellowness $\left(b^{\star}\right)$ & $2.14(1.60-2.85)$ & $2.85(2.20-4.05)$ & $2.47(0.52-2.96)$ & 0.24 & 0.086 & 0.807 \\
\hline
\end{tabular}

T0: control, T10: 10\% replacement of soybean meal with pumpkin seed cake, T15: 15\% replacement of soybean meal with pumpkin seed cake, carcass length 1: os pubis-atlas, carcass length 2: os pubis-first rib; *weight of lungs, heart, liver and spleen; SD-standard deviation, SEM-standard error of mean.

Table 3 Mean $( \pm$ SD) haematological parameters and distribution of leukocytes in the whole blood of lambs

\begin{tabular}{|c|c|c|c|c|c|c|}
\hline \multirow{2}{*}{ Parameters } & \multicolumn{3}{|c|}{ Group } & \multirow{2}{*}{ SEM } & \multirow{2}{*}{$P$-value } & \multirow{2}{*}{$\begin{array}{l}\text { Reference } \\
\text { values* }\end{array}$} \\
\hline & TO & T10 & T15 & & & \\
\hline WBC $\left(\times 10^{9} \mathrm{~L}^{-1}\right)$ & $11.44 \pm 2.68$ & $11.71 \pm 3.76$ & $11.82 \pm 4.27$ & 0.59 & 0.967 & $5.1-15.9$ \\
\hline $\operatorname{RBC}\left(\times 10^{12} \mathrm{~L}^{-1}\right)$ & $7.25 \pm 1.92$ & $7.36 \pm 2.18$ & $7.68 \pm 1.58$ & 0.31 & 0.848 & 9.2-13.0 \\
\hline Haemoglobin, $\mathrm{gL}^{-1}$ & $87.75 \pm 14.99$ & $88.75 \pm 18.71$ & $96.67 \pm 13.86$ & 2.67 & 0.338 & 105.0-137.0 \\
\hline Haematocrit, \% & $0.34 \pm 0.05$ & $0.35 \pm 0.07$ & $0.38 \pm 0.05$ & 0.01 & 0.227 & $0.28-0.39$ \\
\hline $\mathrm{MCV}, \mathrm{fl}$ & $47.90 \pm 6.29$ & $49.28 \pm 6.60$ & $50.47 \pm 6.29$ & 1.05 & 0.621 & $28.0-35.0$ \\
\hline $\mathrm{MCH}, \mathrm{pg}$ & $12.38 \pm 1.24$ & $12.40 \pm 1.64$ & $12.80 \pm 1.51$ & 0.24 & 0.732 & $10.0-13.0$ \\
\hline $\mathrm{MCHC}, \mathrm{gL}^{-1}$ & $259.75 \pm 17.09$ & $251.67 \pm 6.07$ & $254.00 \pm 9.96$ & 2.01 & 0.248 & $332.0-392.0$ \\
\hline $\operatorname{PLT}\left(\times 10^{9} \mathrm{~L}^{-1}\right)$ & $445.25 \pm 243.39$ & $400.67 \pm 253.47$ & $575.33 \pm 216.09$ & 40.85 & 0.196 & $426.0-1142.0$ \\
\hline \multicolumn{7}{|c|}{ Distribution of leukocytes, \% } \\
\hline Lymphocytes & $70.50 \pm 10.75$ & $60.45 \pm 5.70$ & $66.17 \pm 13.07$ & 1.85 & 0.085 & $50.0-70.0$ \\
\hline Neutrophils seg. & $28.50 \pm 11.18$ & $38.00 \pm 6.26$ & $32.25 \pm 12.62$ & 1.84 & 0.101 & $10.0-50.0$ \\
\hline Eosinophils & $1.00 \pm 0.85$ & $1.09 \pm 1.04$ & $1.33 \pm 1.13$ & 0.17 & 0.729 & $1.0-8.0$ \\
\hline Monocytes & ND & $0.46 \pm 0.68$ & ND & 0.07 & 0.395 & $0.0-4.0$ \\
\hline Basophils & ND & ND & $0.08 \pm 0.28$ & 0.03 & 0.063 & $0.0-1.0$ \\
\hline
\end{tabular}


Table 4 Mean $( \pm S D)$ serum biochemical parameters and certain enzyme activities of lambs

\begin{tabular}{|c|c|c|c|c|c|c|}
\hline \multirow{2}{*}{$\begin{array}{l}\text { Parameters, } \\
\text { mmol L }^{-1}\end{array}$} & \multicolumn{3}{|c|}{ Group } & \multirow{2}{*}{ SEM } & \multirow{2}{*}{$P$-value } & \multirow{2}{*}{$\begin{array}{l}\text { Reference } \\
\text { values** }\end{array}$} \\
\hline & то & T10 & T15 & & & \\
\hline Glucose & $4.33^{\mathrm{a}} \pm 0.51$ & $4.78^{\mathrm{b}} \pm 0.44$ & $4.82^{\mathrm{b}} \pm 0.47$ & 0.08 & 0.029 & $2.7-4.8$ \\
\hline Cholesterol & $1.10^{a} \pm 0.33$ & $1.02^{\mathrm{ab}} \pm 0.23$ & $0.87^{b} \pm 0.12$ & 0.04 & 0.028 & $1.04-1.67$ \\
\hline HDL-cholesterol & $0.62 \pm 0.08$ & $0.67 \pm 0.20$ & $0.69 \pm 0.13$ & 0.02 & 0.542 & $0.68-0.97^{1}$ \\
\hline LDL-cholesterol & $0.30 \pm 0.39$ & $0.20 \pm 0.10$ & $0.13 \pm 0.07$ & 0.03 & 0.206 & $0.10-0.50^{1}$ \\
\hline Triglycerides & $0.30 \pm 0.08$ & $0.29 \pm 0.06$ & $0.27 \pm 0.06$ & 0.01 & 0.593 & $0.20-0.40^{1}$ \\
\hline NEFA & $0.07^{\mathrm{a}} \pm 0.04$ & $0.04^{b} \pm 0.02$ & $0.04^{b} \pm 0.06$ & 0.01 & 0.007 & ND \\
\hline Urea & $6.95^{\mathrm{a}} \pm 1.70$ & $6.48^{\mathrm{ab}} \pm 1.01$ & $5.81^{\mathrm{b}} \pm 1.05$ & 0.22 & 0.039 & $5.00-9.10$ \\
\hline Total protein, $\mathrm{g} \mathrm{L}^{-1}$ & $62.99 \pm 4.35$ & $64.60 \pm 4.59$ & $66.52 \pm 4.50$ & 0.77 & 0.171 & $51.00-64.00$ \\
\hline Albumin, $\mathrm{g} \mathrm{L}^{-1}$ & $27.93^{\mathrm{a}} \pm 1.23$ & $28.26^{\mathrm{ab}} \pm 1.88$ & $29.69^{b} \pm 2.06$ & 0.31 & 0.045 & $30.00-37.00$ \\
\hline Globulin, $\mathrm{g} \mathrm{L}^{-1}$ & $35.07 \pm 3.88$ & $36.34 \pm 3.97$ & $36.83 \pm 3.67$ & 0.63 & 0.095 & $19.00-30.00$ \\
\hline $\mathrm{BHB}$ & $0.36^{\mathrm{a}} \pm 0.10$ & $0.28^{\mathrm{b}} \pm 0.09$ & $0.31^{\mathrm{b}} \pm 0.09$ & 0.02 & 0.045 & $0.20-0.70$ \\
\hline Calcium & $2.30 \pm 0.17$ & $2.43 \pm 0.10$ & $2.39 \pm 0.15$ & 0.03 & 0.106 & $2.45-2.92$ \\
\hline Phosphorus-inorg. & $2.30 \pm 0.21$ & $2.25 \pm 0.32$ & $2.22 \pm 0.31$ & 0.05 & 0.773 & $1.88-3.34$ \\
\hline Iron, $\mu \mathrm{mol} \mathrm{L} \mathrm{L}^{-1}$ & $23.87 \pm 6.62$ & $23.52 \pm 5.98$ & $26.20 \pm 5.44$ & 1.00 & 0.503 & $17.1-33.3^{1}$ \\
\hline$A L T, \cup L^{-1}$ & $11.72 \pm 4.14$ & $11.20 \pm 3.87$ & $14.22 \pm 5.11$ & 0.75 & 0.213 & $8.0-20.0^{2}$ \\
\hline AST, $\cup L^{-1}$ & $92.98 \pm 26.84$ & $89.95 \pm 12.15$ & $81.21 \pm 17.46$ & 3.33 & 0.277 & $83.0-140.0$ \\
\hline GPx, $\mathrm{UL}^{-1}$ & $432.06 \pm 110.1$ & $454.24 \pm 93.94$ & $464.12 \pm 65.56$ & 15.01 & 0.694 & $>600^{3}$ \\
\hline SOD, $\mathrm{U} \mathrm{mL}^{-1}$ & $0.12^{\mathrm{a}} \pm 0.07$ & $0.21^{\mathrm{a}} \pm 0.10$ & $0.27^{b} \pm 0.13$ & 0.02 & 0.002 & $0.184^{4}$ \\
\hline
\end{tabular}

T0: control, T10: 10\% replacement of soybean meal with pumpkin seed cake, T15: 15\% replacement of soybean meal with pumpkin seed cake; HDL: high-density lipoprotein, LDL: low-density lipoprotein, NEFA: non-esterified fatty acids, BHB: betahydroxybutyrate, ALT: alanine aminotransferase, AST: aspartate aminotransferase, GPx: glutathione peroxidase, SOD: superoxide dismutase; SD-standard deviation, SEM: standard error of mean, ND: not determined; *Lepherd et al. (2009)

${ }^{1}$ Antunović et al. (2010) determined in lambs during the research

${ }^{2}$ Kaneko et al. (2008) for sheep

${ }^{3}$ Pavlata et al. (2012)-value determined in $\mu \mathrm{kat} / \mathrm{L}$ of whole blood of sheep

${ }^{4}$ Maan et al. (2013)-value determined in sheep

${ }^{a}, \mathrm{~b}$ Rows means with different superscripts differ significantly at $P<0.05$.

Table 5 presents the FA concentrations in the meat of lambs fed with $10 \%$ or $15 \%$ pumpkin seed cake compared with the control group. Median values of $\mathrm{C} 16: 1$ were lower $(P<0.05)$ in both experimental groups compared with the control. Replacing soybean meal with $10 \%$ and $15 \%$ pumpkin seed cake in the mixture of lambs led to a higher concentration of LA in meat than in the control group. The elevated content of LA led to an increased ratio between $n-6$ and $n-3$ in both experimental groups, compared with the control group. Medians of OA, conjugated linoleic acid (CLA), a-linolenic acid (ALA), eicosapentaenoic acid (EPA) and docosahexaenoic acid (DHA) concentrations in lamb meat did not differ in T10 and T15 compared with control. The concentration of total SFA, monounsaturated fatty acids (MUFA) and PUFA did not differ when feeding lambs the diets containing $10 \%$ or $15 \%$ pumpkin seed cake.

\section{Discussion}

Replacing $10 \%$ and $15 \%$ soybean meal with pumpkin seed cake resulted in carcass traits similar to that in the control group, which means that the higher crude protein and ether extract contents (Table 1) of the experimental diets did not affect carcass traits. In research by Santos et al. (2013), lambs were fed diets which contained sunflower cake, peanut cake or soybean cake, all with a high ether extract content, and carcass traits were not affected. Also, experimental diets in the present study did not influence the colour parameters of the $m$. semimembranosus. These parameters were adequate for lambs of this age, as reported also by Držaić et al. (2016). 
Table 5 Median (min-max) value of fatty acid concentrations in musculus semimembranosus of lambs

\begin{tabular}{|c|c|c|c|c|c|c|}
\hline \multirow{2}{*}{$\begin{array}{l}\text { Fatty acids } \\
\text { (g/100 g total } \\
\text { fatty acids) }\end{array}$} & \multicolumn{3}{|c|}{ Group } & \multirow{2}{*}{ SE } & \multicolumn{2}{|c|}{$P$-values } \\
\hline & T0 & T10 & T15 & & T0/T10 & T0/T15 \\
\hline C10:0 & $0.19(0.02-0.34)$ & $0.23(0.14-0.31)$ & $0.25(0.21-0.30)$ & 0.02 & 0.917 & 0.602 \\
\hline C12:0 & $0.41(0.23-0.70)$ & $0.48(0.31-0.70)$ & $0.48(0.42-0.67)$ & 0.04 & 0.465 & 0.347 \\
\hline C14:0 & $5.18(3.23-6.24)$ & $5.52(4.45-6.00)$ & $5.42(3.66-6.66)$ & 0.27 & 0.465 & 0.175 \\
\hline C16:0 & $22.99(20.73-23.40)$ & $23.25(22.78-23.70)$ & $23.67(21.61-24.11)$ & 0.24 & 0.175 & 0.347 \\
\hline C16:1 & $1.97(1.67-2.06)$ & $1.61(1.56-1.81)$ & $1.77(1.46-1.82)$ & 0.05 & 0.028 & 0.047 \\
\hline C18:0 & $24.71(24.16-38.50)$ & $27.92(25.14-33.10)$ & $25.37(21.35-33.63)$ & 1.21 & 0.347 & 0.602 \\
\hline C18:1 t9 & $4.18(2.89-5.57)$ & $4.91(0.57-5.81)$ & $4.74(4.42-6.02)$ & 0.35 & 0.465 & 0.251 \\
\hline C18:1 c9 (OA) & $34.23(25.29-36.10)$ & $30.33(28.10-31.89)$ & $31.42(28.02-34.63)$ & 0.75 & 0.175 & 0.347 \\
\hline C18:2 c9t11 (CLA) & $0.29(0.09-0.47)$ & $0.25(0.21-0.32)$ & $0.30(0.11-0.31)$ & 0.03 & 0.462 & 0.754 \\
\hline C18:2 n6 (LA) & $3.16(2.72-3.58)$ & $3.90(3.43-5.38)$ & $4.05(3.66-4.40)$ & 0.17 & 0.028 & 0.009 \\
\hline C18:3 n3 (ALA) & $0.66(0.49-1.55)$ & $0.61(0.52-0.69)$ & $0.65(0.57-0.70)$ & 0.06 & 0.602 & 0.754 \\
\hline C23:0 & $0.16(0.14-0.21)$ & $0.20(0.13-0.30)$ & $0.14(0.11-0.66)$ & 0.04 & 0.327 & 0.462 \\
\hline C20:4 n6 (AA) & $0.03(0.02-0.03)$ & $0.04(0.02-0.05)$ & $0.03(0.02-0.03)$ & 0.004 & 0.248 & 0.643 \\
\hline C24:0 & $0.02(0.01-0.03)$ & $0.03(0.01-0.03)$ & $0.01(0.01-0.08)$ & 0.005 & 0.476 & 0.476 \\
\hline C20:5 n3 (EPA) & $0.04(0.03-0.04)$ & $0.04(0.02-0.04)$ & $0.02(0.02-0.06)$ & 0.006 & 0.721 & 0.384 \\
\hline C22:6 n3 (DHA) & $0.02(0.01-0.03)$ & $0.03(0.02-0.06)$ & $0.02(0.01-0.06)$ & 0.005 & 0.245 & 0.772 \\
\hline LA/ALA & $4.93(2.31-5.64)$ & $6.62(5.18-8.83)$ & $6.18(5.62-7.66)$ & 0.39 & 0.028 & 0.016 \\
\hline SFA & $56.21(53.25-63.19)$ & $57.43(55.41-62.28)$ & 55.39 (53.94-60.35) & 0.83 & 0.465 & 0.754 \\
\hline PUFA & $4.15(3.61-5.60)$ & $4.69(4.43-6.29)$ & $5.06(4.76-5.42)$ & 0.18 & 0.117 & 0.117 \\
\hline MUFA & $39.62(32.36-42.37)$ & $37.63(32.40-39.32)$ & $38.89(34.28-41.29)$ & 0.83 & 0.117 & 0.602 \\
\hline UFA & $43.77(36.82-46.75)$ & $42.53(37.72-44.01)$ & $43.95(39.63-46.04)$ & 0.82 & 0.465 & 0.754 \\
\hline
\end{tabular}

T0: control, T10: 10\% replacement of soybean meal with pumpkin seed cake, T15: 15\% replacement of soybean meal with pumpkin seed cake; ND: not determined; OA: oleic acid; CLA: conjugated linoleic acid; LA: linoleic acid; ALA: alphalinolenic acid; AA: arachidonic acid; EPA: eicosapentaenoic acid; DHA: docosahexaenoic acid; SFA (saturated fatty acids): C10:0, C12:0, C13:0, C14:0, C16:0, C18:0, C20:0, C23:0, C24:0; PUFA (polyunsaturated fatty acids): C18:2 c9 t11, C18:2, C18:3, , C20:3, C20:4, C20:5, C22:6; MUFA (monounsaturated fatty acids): C16:1, C18:1 t9, C18:1 c9; UFA (unsaturated fatty acids): sum of MUFA and PUFA; SEM: standard error of mean

The T15 diet in the current study promoted lower $(P<0.05)$ concentrations of cholesterol in serum, emphasizing the positive influence of pumpkin seed cake on fat metabolism. However, pumpkin seeds contain high concentrations of phytosterols (Patel, 2013), which may decrease both total serum cholesterol and LDLcholesterol in humans by inhibiting the absorption of dietary cholesterol (Piironen et al., 2000). In the literature, there is no study that investigated the use of pumpkin seed cake in the feeding of sheep and lambs. Results obtained in the current study could therefore not be compared with other investigations. However, adding pumpkin oil to the diets of broiler chickens lowered $(P<0.05)$ cholesterol and triglyceride concentrations in plasma (Hajati et al., 2011). Makni et al. (2010) carried out a study on rats with alloxan-induced diabetes and added linseed and pumpkin seeds to the feed to determine lower concentrations of cholesterol, triglycerides, LDL- and enhanced HDL-cholesterol, which is known to play an important role in the transportation of cholesterol from peripheral cells to the liver by a pathway termed reverse cholesterol transport, thus regarded as a cardio protective. Higher concentrations of glucose and albumin, as well as lower NEFA and BHB concentrations in the serum of lambs fed with pumpkin seed cake emphasize adequate energy status, since high levels of NEFA and glucose concentration are indicators of lipid metabolism and fatty acid oxidation (Wathes et al., 2009). Lower haemoglobin content and red blood cells were determined in the blood of lambs fed pumpkin seed cake replacement compared with reference values for sheep, which might be related to the age of the lambs. Bornez et al. (2009) found that haemoglobin level and erythrocytes increased with the ageing of lambs. Based on the results of haemato-chemical parameters, it is evident that the health status of lambs was stable in the experimental groups. Higher activity of SOD in the group fed T15 was determined in the present study, while 
activity of GPx did not differ. Replacement with $10 \%$ of pumpkin seed cake did not lead to differences in SOD and GPX activity. Vazguez-Anon et al. (2008) stated that SOD activity in the plasma of dairy cows depends on the antioxidant level in the diets, but the effect was dependent on the type of fat in the diets, with the highest activity being observed when oxidized fat was added. Makni et al. (2008) indicated that feeding a mixture that was rich in flax and pumpkin seed, when adequately supplemented in standard diets, affected the higher activities of antioxidant enzymes, such as SOD, catalase, and GPx, and reduced the glutathione level in plasma and liver of hypercholesterolemic rats. In the present study, the higher activity of SOD in T15 was probably due to PUFA in the diets, which was also observed in meat, although this was not significant. The first line of defence against oxygen-derived free radicals occurs when SOD catalyses the dismutation of the superoxide anion into hydrogen peroxide (Dursun et al., 2006). The lipoperoxidation process, influenced by PUFA, increased SOD activity, although GPx activity was not influenced by feeding treatment, indicating stable antioxidant status of the experimental groups. The activity of GPx in serum was according to the values ascertained in whole blood of sheep by Pavlata at al. (2012). The GPx activity determined in bovine plasma/serum constituted only $0.5-2.0 \%$ of total activity in whole bovine blood (Ortman, 1999). Besides fatty acids, such results could be influenced by phenolic acids in pumpkin seed cake (Peričin et al., 2009), which increase the activities of hepatic antioxidant enzymes, such as SOD and GPx, as found in rats by Yeh \& Yen (2006). Since SOD and GPx activities were not lowered compared with the control group in the present study, the antioxidant status was preserved. These observations indicate that the stable antioxidant status of lambs was adequate owing to proper antioxidant levels in the diets and the desirable energy condition of the lambs.

The fatty acid concentrations in $\mathrm{m}$. semimembranosus of lambs in T10 and T15 are presented in Table 5. Fatty acid concentration was established only in $m$. semimembranosus, which could be a limitation of the present study, since the fatty acid profile may differ among muscle types, as reported by Popova (2007), for instance between $m$. longissimus lumborum and $m$. semimembranosus. On the Croatian market, lamb is usually sold as a whole carcass. For this reason only the semimembranosus muscle was taken to avoid damaging the carcass. Thus, samples of the fatty acid profile of other muscles could not be obtained in the current experimental setup. Replacing soybean meal with $10 \%$ and $15 \%$ pumpkin seed cake in the mixture led to higher median value of LA concentrations in m. semimembranosus. LA is contained in pumpkin seed oil at a level of 35.6-60.8\% (Murković et al., 1996) and in the pumpkin seed cake mixture (Table 1). Although the control diet was rich in LA as well, the highest content of LA was obtained in the T10 and T15 treatments. Actually, owing to the hydrogenation by rumen microbes, most PUFAs are converted to SFA in the rumen and only a small percentage of PUFA escapes ruminal conversions (Wood et al., 2008). According to the present study, probably more LA escaped the effect of the rumen when using T10 and T15. Elevated LA content led to a higher ratio between $n-6$ and $n-3$, when compared with the control group, which was not favourable, because the recommendation for $n-6 / n-3$ ratio in human diet should be lower than 4 . The $n-6 / n-3$ ratio is required to maintain the balance of inflammatory and anti-inflammatory properties (Simopoulos, 2008). Simopoulos (2002) reviewed that humans evolved on a diet with a ratio of n-6 to n-3 essential fatty acids of approximately 1, whereas that ratio increased in Western diets (15/1-16.7/1), which is unfavourable. In the present study the inclusion of $10 \%$ and $15 \%$ pumpkin seed cake in the diets did not lower the contents of other important fatty acids in the $m$. semimembranosus, such as OA and CLA, and n-3 fatty acids, such as ALA, EPA and DHA, which are generally regarded as being beneficial to human health (Scollan et al., 2005). According to the European Parliament and Council (2006), food is a good source of $n-3$ fatty acids if the product contains at least $0.3 \mathrm{~g}$ ALA per $100 \mathrm{~g}$ and the sum of EPA and DHA is at least $40 \mathrm{mg} / 100 \mathrm{~g}$. When compared with the control diet in the present study, this suggests that pumpkin seed cake may be a good source of MUFA and PUFA when feeding lambs, although, owing to the high content of LA, the ratio between LA and ALA could be higher. In the present research levels of pumpkin seed cake replacing soybean meal at lower than $10 \%$ and higher than $15 \%$ were not considered. Thus, it is not known how these levels would affect production traits, meat quality and fatty acid proportions in lamb meat and is worth further investigations.

\section{Conclusion}

Partial replacement of soybean meal with pumpkin seed cake promoted adequate carcass characteristics and is feasible with respect to changes in haemato-chemical parameters of lambs' blood in organic farming. Replacing soybean meal with $10 \%$ and $15 \%$ of pumpkin seed cake had less favourable effects owing to higher contents of LA and a higher LA/ALA ratio in $\mathrm{m}$. semimembranosus. Thus, pumpkin seed cake could be used in lamb feed as a replacement for soybean meal in terms of the haemato-chemical parameters and carcass traits. In future research it is necessary to obtain more levels of replacement with pumpkin seed cake and to research its antioxidant potential in lamb feed. 


\section{Acknowledgements}

The research required for the present study was part of the VIP project financed by the Ministry of Agriculture, Republic of Croatia.

\section{Author's contributions}

ZA designed the experiment and wrote the paper. JN and ZK collected samples, analysed results, and prepared the paper for submission. MS carried out the biochemical analyses. DC prepared samples and analysed the fatty acid profile. VS collected samples and BM participated in the interpretation of the results.

\section{Conflict of interest declaration}

The authors declare that they have no conflicts of interest.

\section{References}

Adeyemi, K.D., Ismail, M., Ebrahimi, M., Sabow, A.B., Shittu, R.M., Karim, R. \& Sazili, A.Q., 2016. Fatty acids, lipid and protein oxidation, metmyoglobin reducing activity and sensory attributes of biceps femoris muscle in goats fed a canola and palm oil blend. S. Afr. J. Anim. Sci. 46, 139-151.

Alves, F.J.L., de Andrade Ferreira, M., Antas Urbano, S., de Andrade, R.P.X., da Silva, A.E., Siquiero, M.C.B., de Oliveira, J.P.F. \& de Lima Silva, J., 2016. Performance of lambs fed alternative protein sources to soybean meal. Rev. Bras. Zootecn. 45(4), 145-150.

Antunović, Z., Novoselec, J., Senčić, Đ., Šperanda, M., Steiner, Z. \& Samac, D., 2010. Production traits and blood biochemical parameters in organic lamb production. In: Proceedings of the 45th Croatian \& 5th International Symposium on Agriculture. Ed. Marić, S., Lončarić, Z., Opatija, Croatia. pp. 1014-1018.

Antunović, Z., Novoselec, J. \& Klir, Ž., 2017a. Hematological parameters in ewes during lactation in organic farming. Poljoprivreda/Agriculture. 23(2), 46-52.

Antunović, Z., Klir, Ž., Šperanda, M., Ćavar, S., Mioč, B. \& Novoselec, J., 2017b. Production traits, blood metabolic profile and fatty acids of meat and tallow in response to the partial replacement of soybean meal with peas in organic lambs' feed. Arch. Anim. Breed. 60, 409-417.

Bornez, R., Linares, M.B. \& Vergara, H., 2009. Haematological, hormonal and biochemical blood parameters in lamb: Effect of age and blood sampling time. Livest. Sci. 121, 200-206.

CIE-Commission Internationale de l'Eclairage, 1976. Colorimetry: Official Recommendations of the International Commission on Illumination. Publication CIE No. 15 (E- 1.3.1). Bureau Central de la CIE, Paris, France.

Čolović, D., Ilić, N., Okanović, Đ. \& Palić, D., 2012. Heat treatment effect on fatty acid composition in different pig tissues. Food Feed Res. 39, 89-96.

Demirel, G., Ozpinar, H., Nazli, \& Keser, O., 2006. Fatty acids of lamb meat from two breeds fed different forage: concentrate ratio. Meat Sci. 72, 229-235.

Držaić, V., Kaić, A., Širić, I., Antunović, Z. \& Mioč, B., 2016. Colour and pH value of Istrian sheep lambs meat. Poljoprivreda/Agriculture. 22(1), 39-45.

Dursun, H., Bilici, M., Uyanik, A., Okcu, N. \& Akyüz, M., 2006. Antioxidant enzyme activities and lipid peroxidation levels in erythrocytes of patients with oesophageal and gastric cancer. J. Int. Med. Res. 34, 193 -199.

Elmore, J.S., Cooper, S.L., Enser, M., Mottram, D.S., Sinclair, L.A., Wilkinson, R.G. \& Wood, J.D., 2005. Dietary manipulation of fatty acid composition in lamb meat and its effect on the volatile aroma compounds of grilled lamb. Meat Sci. 69, 233-242.

Enishi, O., Yoshioka, T., Nakashima, K., Saeki, M. \& Kawashima, T., 2004. Analysis of in situ ruminal digestive characteristics and nutritive value of pumpkin and carrot juice residue for ruminant feeds. Grassl. Sci. 50, 360-365.

European Parliament and Council 200. Regulation (EC) No. 1924/2006 on Nutritional and Health Claims Made on Foods, 2006. Council Regulation (EC) No. 834/2007 on Organic Production and Labelling of Organic Products with regard to Organic Production, Labelling and Control. Official Journal of the European Union (OJ), 2007.

Folch, J., Lees, M. \& Sloane-Stanley, G.H., 1957. A simple method for the isolation and purification of total lipids from animal tissues. J. Biol. Chem. 226, 497-509.

Foss, 2001. Determination of acid detergent fiber (ADF) and acid detergent lignin in feed and forage using FiberCap ${ }^{\mathrm{TM}}$ 2021/2023 in agreement with EN ISO 13906:2008. Foss Tecator AB, Sweden.

Glew, R.H., Glew, R.S., Chuang, L.T., Huang, Y.S. \& Millson, M., 2006. Amino acid, mineral and fatty acid content of pumpkin seeds (Cucurbita spp) and Cyperus esculentus nuts in the Republic of Niger. Plant Foods Hum. Nutr. 61, 51-56.

Hajati, H., Hasanabadi, A. \& Waldroup, P.W., 2011. Effects of dietary supplementation with pumpkin oil (Cucurbita pepo) on performance and blood fat of broiler chickens during finisher period. Am. J. Anim. Vet. Sci. 6(1), 40-44.

Hewlett, K.L. \& Azeez, G.S.E., 2008. The economic impact of GM contamination incidents on the organic sector. Proc. of 16th IFOAM Organic World Congress, 'Cultivate the Future', Modena, Italy, 18-20 June 2008 http://orgprints.org/view/projects/conference.html.

Juranovic, I., Breinhoelder, P. \& Steffan, I., 2003. Determination of trace elements in pumpkin seed oils and pumpkin seeds by ICP-AES. J. Anal. Atom. Spectrometry 18, 54-58.

Kaneko, J.J., Harvey, J.W. \& Bruss, M.L., 2008. Clinical Biochemistry of Domestic Animals. Amsterdam, Netherlands, Elsevier/Academic Press, $6^{\text {th }}$ ed., $963 \mathrm{pp}$. 
Klir, Z., Castro-Montoya, J.M., Novoselec, J., Molkentin, J., Domacinovic, M., Mioc, B., Dickhoefer, U. \& Antunovic, Z., 2017. Influence of pumpkin seed cake and extruded linseed on milk production and milk fatty acid profile in Alpine goats. Animal 11(10), 1772-1778.

Latimer, K.S. \& Prasse, K., 2003. Leukocites. In: K.S. Latimer, E.A. Maheffey \& K.W. Prasse (eds). Duncan and Prasse's Veterinary Laboratory Medicine-Clinical Pathology. Iowa State University Press, Ames.

Lepherd, M., Canfield, P.J., Hunt, G.B. \& Bosward, K.L., 2009. Haematological, biochemical and selected acute phase protein reference intervals for weaned female Merino lambs. Aus. Vet. J. 87, 5-11.

Maan, R., Kataria, N., Pilania, P.K., Sharma, A., Arora, S., Joshi, A., Sankhala, L.N., Sharma, S.K., Mohammad, N., Nathawat, P. \& Kataria, A.K., 2013. Superoxide dismutase profiling during extreme ambiences in Marwari sheep from arid tracts. Vet. Res. 6, 15-18.

Makni, M., Sefi, M., Fetoui, H., Garoui, E.M., Gargouri, N.K., Boudawara, T. \& Zeghal, N., 2010. Flax and pumpkin seeds mixture ameliorates diabetic nephropathy in rats. Food Chem. Toxicol. 48, 2407-2412.

Makni, M., Fetoui, H., Gargouri, N.K., Garoui, E.M., Jaber, H., Makni, J., Boudawara, T. \& Zeghal, N., 2008. Hypolipidemic and hepatoprotective effect of flax and pumpkin seed mixture rich in $\omega-3$ and $\omega-6$ fatty acids in hypercholesterolemic rats. Food Chem. Toxicol. 46, 3714-3720.

Murković, M., Hillebrand, A., Winkler, A., Leitner, E. \& Pfannhauser, W., 1996. Variability of fatty acid content in pumpkin seeds (Cucurbita pepo L.). Z. Lebensm. Unters. For. 203, 216-219.

Offor, I.F., Ehiri, R.C. \& Njoku, C.N., 2014. Proximate nutritional analysis and heavy metal composition of dried Moringa Oleifera leaves from Oshiri Onicha L.G.A, Ebonyi State, Nigeria. IOSR-JESTFT 8, 57-62.

Onwuka, G.I., 2005. Food Analysis and Instrumentation: Theory and Practice. Naphthali Prints, Lagos, Nigeria.

Ortman, K., 1999. Organic vs inorganic selenium in farm animal nutrition with special reference to supplementation of cattle. Doctoral thesis, Swedish University of Agricultural Sciences, Veterinaria 45, Uppsala, Sweden.

Patel, S., 2013. Pumpkin (Cucurbita sp.) seeds as nutraceutic: A review on status quo and scope. Mediterr. J. Nutr. Metab. 6, 183-189.

Pavlata, L., Misurova, L., Pechova, A., Husakova, T. \& Dvorak, R., 2012. Direct and indirect assessment of selenium status in sheep - a comparison. Vet. Med. 57, 219-223.

Pearson, D.A., 1976. The Chemical Analysis of Foods. 7th edition. Churchill Livingstone, Edinburgh, Scotland.

Peričin, D., Krimer, V., Trivić, S. \& Radulović, L., 2009. The distribution of phenolic acids in pumpkin hull-less seed, skin, oil cake meal, dehulled kernel and hull. Food Chem. 113(2), 450-456.

Piironen, V., Lindsay, D.G., Miettinen, T.A., Toivo, J. \& Lampi, A.M., 2000. Plant sterols: Biosynthesis, biological function and their importance to human nutrition. J. Sci. Food Agric. 80, 933-966.

Ponnampalam, E.N., Sinclairt, A.J., Egan, A.R., Blakeley, S.J. \& Leury, B.J., 2001. Effect of diets containing n-3 fatty acids on muscle long-chain n-3 fatty acid content in lambs fed low- and medium-quality roughage diets. J. Anim. Sci. 79, 698-706.

Popova, T., 2007. Effect of the rearing system on the fatty acid composition and oxidative stability of the M. longissimus lumborum and $M$. semimembranosus in lambs. Small Rumin. Res. 71, 150-157.

Rahmann, G., 2009. Ökologische Schaf- und Ziegenhaltung. 100 Fragen und Antworten für die Praxis. 2., Überarbeitete Auflage. Institut für Ökologischen Landbau (OEL), Westerau, Deutschland.

Santos, V.C., Bertocco Ezequiel, J.M., da Silva Morgado, E. \& de Sousa Junior, S.C., 2013. Carcass and meat traits of lambs fed by-products from the processing of oil seeds. Acta Scient. 35(4), 387-394.

Sarhan, M., 2011. Use of legume grains in organic animal feeding. Effect on sheep milk yield and quality. DOI: 10.13140/2.1.3167.8246

SAS Institute, 2002-2012: SAS $9.4^{\circledR}$, Inc., Cary, NC, USA.

Scollan, N.D., Richardson, I. \& Moloney, A.P., 2005. Effect of beef systems on meat composition and quality. Proc. of 18th Annual Langford Food Industry Conference, Bristol, UK, pp. 5

Siegmund, B. \& Murkovic, M., 2004. Changes in chemical composition of pumpkin seeds during the roasting process for production of pumpkin seed oil. 2. Volatile compounds. Food Chem. 84, 367-374.

Simopoulos, A.P., 2002. The importance of the ratio of omega-6/omega-3 essential fatty acids. Biomed. Pharmacother. 56, 365-79.

Simopoulos, A.P., 2008. The importance of the omega-6/omega-3 fatty acid ratio in cardiovascular disease and other chronic diseases. Exp. Biol. M. (Maywood). 233, 674-688.

Vazquez-Anon, M., Nocek, J., Bowman, G., Hampton, T., Atwell, C., Vázquez, P. \& Jenkins, T., 2008. Effects of feeding a dietary antioxidant in diets with oxidized fat on lactation performance and antioxidant status of the cow. J. Dairy Sci. 91, 3165-3172.

Wathes, D.C., Cheng, Z., Chowdhury, W., Fenwick, M.A., Fitzpatrick, R., Morris, D.G., Patton, J. \& Murphy, J.J., 2009. Negative energy balance alters global gene expression and immune response in the uterus of postpartum dairy cows. Physiol. Genom. 39, 1-13.

Wood, J.D., Enser, M., Fisher, A.V., Nute, G.R., Sheard, P.R., Richardson, R.I., Hughes, S.I. \& Whittington, F.M., 2008. Fat deposition, fatty acid composition and meat quality: A review. Meat Sci. 78, 343-358.

Yeh, C.T. \& Yen, G.C., 2006. Induction of hepatic antioxidant enzymes by phenolic acids in rats is accompanied by increased levels of multidrug resistance-associated protein 3 mRNA expression. J. Nutr. 136, 11-5.

Zdunczyk, Z., Minakowski, D., Frejnage, L.S. \& Flis, M., 1999. Comparative study of the chemical composition and nutritional value of pumpkin seed cake, soybean meal and casein. Nahrung 43, 392-395. 